\title{
PERBEDAAN EFISIENSI PERUSAHAAN ASURANSI JIWA SYARIAH DAN KONVENSIONAL DI INDONESIA DENGAN METODE DATA ENVELOPMENT ANALYSIS (DEA)'
}

\author{
Yurike Fitria Astuti \\ Mahasiswa Program Studi S1 Ekonomi Islam-Fakultas Ekonomi dan Bisnis-Universitas Airlangga \\ Email: yurike.fitria-13@feb.unair.ac.id \\ Noven Suprayogi \\ Departemen Ekonomi Syariah-Fakultas Ekonomi dan Bisnis-Universitas Airlangga \\ Email: noven.suprayogi@feb.unair.ac.id
}

\begin{abstract}
ABTRACT:
This study aims to determine and comparing the level of operational efficiency of Islamic Life Insurance and Conventional Life Insurance in Indonesia. This study uses a quantitative non-parametric approach With Data Envelopment Analysis (DEA) CRS and VRS assumption, and a statistical tool Mann-Whitney U-Test. The samples are 13 Islamic Insurance and 5 Conventional Insurance that comply with the specified sample criteria. During 2010 to 2014, the relative average value of Islamic Life Insurance and Conventional Life Insurance with VRS assumption more efficient than CRS assumption. This indicates that in relative terms, the source of operational inefficiency is not effective on the efficiency scale. While the hypothesis test results showed no significant differences in levels of operational efficiency in both groups the data by CRS assumptions and VRS.
\end{abstract}

Keywords: Efficiency, Islamic Life Insurance, non-parametrik, Data Envelopment Analysis (DEA).

\section{PENDAHULUAN}

\section{Latar Belakang}

Salah satu sektor lembaga kevangan syariah yang mengalami peningkatan setelah perbankan syariah adalah Industri Asuransi Syariah. Asuransi dengan prinsip syariah merupakan sebuah lembaga keuangan yang menawarkan jasa pengelolaan risiko dengan prinsip syariah. Risiko tersebut dapat terjadi kapan saja, dimana saja, dan kepada siapa saja. Risiko dapat berupa kehilangan, kerusakan, kebakaran, kematian, sakit, bencana alam dan lain sebagainya. Pengolahan risiko asuransi syariah tidak berdasarkan pada prinsip transfer risk sebagaimana pada Asuransi Konvesional melainkan dengan sharing risk dimana para peserta saling tolongmenolong dan melindungi dalam upaya menghadapi risiko. 1 Jurnal ini merupakan bagian dari skripsi yang ditulis oleh Yurike Fitria Astuti, NIM : 041311433083 , yang divji pada 19 Januari 2017

Asuransi di Indonesia dibagi menjadi tiga jenis yaitu Asuransi Jiwa Syariah, Asuransi Umum Syariah, dan Reasuransi Syariah. Asuransi Jiwa dan Umum Syariah memiliki bentuk seperti Bank Syariah pada umumnya yaitu berbentuk unit dari usaha konvensional dan penuh secara syariah (full syariah). Jumlah kelembagaan antara Asuransi Umum dan Jiwa Syariah bersaing secara kompetitif, keduanya mampu memahami potensi pasar sehingga tumbuh dan berkembang dengan baik dalam hal kelembagaan. (OJK: 2016).

Meskipun secara kelembangaan keduanya bersaing secara kompetitif, hal berbeda diungkapkan dalam segi pertumbuhan kotribusi, aset, dan investasi Asuransi Jiwa Syariah lebih unggul dalam beberapa tahun terakhir. Asosiasi Asuransi Syariah Indonesia mencatat bahwa 
Astuti, et al/Jurnal Ekonomi Syariah Teori dan Terapan Vol. 4 No. 8 Agustus 2017: 668-683; PERBEDAAN EFISIENSI PERUSAHAAN ASURANSI JIWA SYARIAH DAN KONVENSIONAL DI INDONESIA DENGAN METODE DATA ENVELOPMENT ANALYSIS (DEA)

adanya peningkatan dari segi Aset pada periode 2014 sebesar 29,65\% lebih unggul dari Asuransi Umum Syariah dan pada tahun 2015 lebih unggul sebesar 6\%. Hal serupa juga terjadi pada segi Total Investasi yang melebihi pencapaian Asuransi Umum pada tahun 2014 dan 2015. Kontribusi Bruto pada Asuransi Jiwa Syariah juga mengalami pertumbuhan lebih baik pada tahun 2014 sedangkan klaim mengalami penurunan. (AASI: 2016). Perkembangan pesat baik dari segi kelembagaan, Total Aset, Investasi, dan Kontribusi Bruto tidak menjadikan Asuransi Jiwa Syariah di Indonesia menjadi bebas dari hambatan. Pada kenyataannya Asuransi Jiwa Konvensional telah lebih dulu hadir di Indonesia. Perkembangan Asuransi Konvensional di Indonesia dimulai pada awal tahun 1980-an diantaranya seperti AIA Financial, Allianz, Avrist, AXA Mandiri, CIGNA, Prudential, dan Asuransi Sinar Mas hadir yang menawarkan berbagai macam produk perlindungan (Sumber:https://www.asura.co.id/ sejarahdan perkembangan-asuransi-di indonesia, diakses pada tanggal 11 September 2016).

Hingga saat ini Asuransi Konvensioal terdiri dari 50 Asuransi Jiwa, 67 Asuransi Umum, 2 Asuransi Sosial, 3 Asuransi Wajib dan 6 Reasuransi yang terdaftar di Otoritas Jasa Kevangan. Perusahaan asuransi syariah pertama kali didirikan pada tahun 1994 melalui PT Syarikat Takaful Indonesia (STI) yang memiliki dua anak perusahaan, yaitu PT Asuransi Takaful Keluarga (ATK) dan PT
Asuransi Takaful Umum (ATU) kemudian berkembang Asuransi Syariah lain baik dalam bentuk unit maupun penuh hingga saat ini (Puspitasari, 2011 :38).

Tabel 1

Perbandingan Kontribusi Bruto, Total Aset, dan Total Investasi Asuransi Jiwa Syariah dengan Total Industri Asuransi 2014-2015

\begin{tabular}{|c|c|c|c|c|}
\hline Ket & $\begin{array}{c}\text { As. } \\
\text { Syariah }\end{array}$ & $\begin{array}{c}\text { Total } \\
\text { Industri }\end{array}$ & $\begin{array}{c}\text { Market } \\
\text { Share } \\
\text { Syariah }\end{array}$ & $\begin{array}{l}\text { Market Share } \\
\text { Konvensional }\end{array}$ \\
\hline \multicolumn{5}{|c|}{2014} \\
\hline $\begin{array}{c}\text { Kontribusi } \\
\text { Bruto }\end{array}$ & 7,881 & 121,621 & $6.48 \%$ & $93,52 \%$ \\
\hline Total Aset & 18,051 & 341,201 & $5.29 \%$ & $94,71 \%$ \\
\hline $\begin{array}{c}\text { Total } \\
\text { Investasi }\end{array}$ & 16,352 & 294,964 & $5.54 \%$ & $94,46 \%$ \\
\hline \multicolumn{5}{|c|}{2015} \\
\hline $\begin{array}{c}\text { Kontribusi } \\
\text { Bruto }\end{array}$ & 8,813 & 102,421 & $8.60 \%$ & $91,40 \%$ \\
\hline Total Aset & 21,614 & 351,294 & $6.15 \%$ & $93,85 \%$ \\
\hline $\begin{array}{c}\text { Total } \\
\text { Investasi }\end{array}$ & 19,576 & 302,722 & $6.47 \%$ & $93,53 \%$ \\
\hline
\end{tabular}

Sumber:http://www.aasi.or.id/main/data-bisnis2015, diakses pada tanggal 10 September 2016, diolah kembali.

Sebuah permasalahan muncul ketika market share kontribusi bruto, total aset dan total investasi Asuransi Jiwa Syariah berada jauh dibawah Asuransi Konvensional sedangkan ketiga komponen tersebut menjadi faktor yang mempengaruhi variabel efisiensi pada penelitian ini. Jumlah kontribusi bruto yang rendah mempengaruhi keterbatasan total beban yang mampu ditanggung dan jumlah profit yang akan dihasilkan. Total investasi berpengaruh terhadap pendapatan investasi yang diperoleh. Padahal total beban dan total investasi merupakan variabel input sedangkan profit dan pendapatan investasi merupakan variabel output penelitian ini. 
Astuti, et al/Jurnal Ekonomi Syariah Teori dan Terapan Vol. 4 No. 8 Agustus 2017: 668-683; PERBEDAAN EFISIENSI PERUSAHAAN ASURANSI JIWA SYARIAH DAN KONVENSIONAL DI INDONESIA DENGAN METODE DATA ENVELOPMENT ANALYSIS (DEA)

Hal tersebut menimbulkan dugaan besarnya nilai efisiensi yang dihasilkan juga akan lebih rendah dibandingkan dengan Asuransi Jiwa Konvensional melihat komponen variabel efisiensi memiliki market share yang sangat rendah. Oleh sebab itu, pengukuran efisiensi dibutuhkan untuk menilai bagaimana kinerja pengelolaan input pada Asuransi Syariah dalam menghasilkan output telah optimal atau belum melihat nilai market share yang dimiliki jauh lebih rendah dari Asuransi Konvensional.

Efisiensi perusahaan asuransi menunjukkan kemampuan manajerial perusahaan dan keefektifan pengelolaan perusahaan (Mawaddah, 2015). Dalam mengelola kegiatan operasional, perusahaan syariah diharapkan dapat menerapkan manajemen keuangan secara efisien sehingga mampu bertahan dalam ketatnya persaingan di Industri Asuransi Syariah dan Asuransi Konvensional. Konsep efisiensi ini sesuai dalam ayat yang terkandung dalam AlQur'an Surat Al-Israa' (17) ayat 26-27:

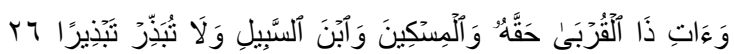

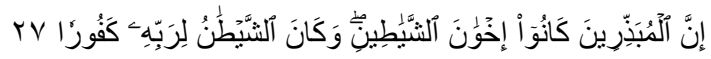
Wa,,āti-żalqurbā haqqahu walmiskinna wabnassabili walā tubażir tabżirā.

„innalmubażirīna-kā nū ,ikhwānasysyayā tạnu-lirabbihi kafūrā

Dan berikanlah kepada keluargakelvarga yang dekat akan haknya, kepada orang miskin dan orang yang dalam perjalanan dan janganlah kamu menghambur-hamburkan (hartamu) secara boros. Sesungguhnya pemborospemboros itu adalah saudara-saudara syaitan dan syaitan itu adalah sangat ingkar kepada Tuhannya (Al Isra 26-27).

Efisiensi Asuransi bertujuan untuk mewujudkan Industri Asuransi yang kuat dan sehat serta dapat memberikan kontribusi besar dalam mendukung pertumbuhan ekonomi di Indonesia. Dari penjelasan diatas maka peneliti akan mengukur, menganalisis dan membandingkan efisiensi perusahaan Asuransi Jiwa Syariah dan Konvensional yang ada di Indonesia tahun 2012-2015. Pengukuran tingkat efisiensi perusahaan Asuransi Jiwa di Indonesia menjadi sesuatu yang sangat penting melihat ketatnya persaingan Industri Asuransi selama rentang waktu tersebut. Pengukuran efisiensi pada penelitian ini menggunakan metode non parametrik dengan Data Envelopment Analysis (DEA). DEA merupakan sebuah teknik pemrograman linier yang mengukur efisiensi relatif dari Decision Making Unit (DMU) yang diperkenalkan oleh Charnes, Cooper dan Rhodes (1978). Decision Making Unit (DMU) merupakan unit pengambil keputusan yang dalam hal ini adalah masing-masing perusahaan Asuransi Jiwa Syariah dan Konvensional yang terpilih menjadi sampel. Teknik pengukuran menggunakan DEA memiliki dua model yaitu CRS (Constant Return to Scale) dan VRS (Variable Return to Scale). Menurut Benarda, dkk (2016) model CRS merupakan pengukuran efisiensi secara 
Astuti, et al/Jurnal Ekonomi Syariah Teori dan Terapan Vol. 4 No. 8 Agustus 2017: 668-683; PERBEDAAN EFISIENSI PERUSAHAAN ASURANSI JIWA SYARIAH DAN KONVENSIONAL DI INDONESIA DENGAN METODE DATA ENVELOPMENT ANALYSIS (DEA)

ekonomis (overall technical) sedangkan model VRS mengukur efisiensi secara teknik (pure technical). Pada dasarnya kinerja model DEA adalah membandingkan output dan input dari suatu decision making unit (DMU) dengan output dan input lainnya pada DMU yang sejenis. Variabel input DEA adalah besarnya sumber daya yang digunakan untuk menghasilkan suatu output dari unit yang bersangkutan sedangkan variabel output dari DEA adalah besarnya nilai yang dihasilkan dari proses penggunaan input.

Konsep pendekatan efisiensi Asuransi menurut Eling (2009) terdiri dari pendekatan nilai tambah yang merupakan gabungan antara pendekatan produksi (operasional) dan intermediasi (investasi) sebagai penentuan variabel input dan output. Variabel input yang digunakan dalam penelitian ini menggunakan total investasi, total modal, total beban sedangkan untuk variabel output adalah profit dan pendapatan investasi.

\section{RUMUSAN MASALAH}

Melalui latar belakang di atas maka rumusan masalah yang dapat dibuat adalah:

1. Apakah terdapat perbedaan efisiensi Asuransi Jiwa Syariah dan Asuransi Jiwa Konvensional Indonesia dengan asumsi CRS?

2. Apakah terdapat perbedaan efisiensi Asuransi Jiwa Syariah dan Asuransi Jiwa Konvensional dengan asumsi VRS?

\section{TUJUAN}

1. Mengetahui, mengukur dan menganalisis tingkat efisiensi Asuransi Jiwa Syariah dan Asuransi Jiwa Konvensional di Indonesia dengan asumsi CRS.

2. Mengetahui,mengukur dan menganalisis tingkat efisiensi Asuransi Jiwa Syariah dan Asuransi Jiwa Konvensional di Indonesia dengan asumsi VRS.

\section{LANDASAN TEORI}

\section{Konsep Dasar Asuransi}

Secara definisi Undang-undang No. 2 Tahun 1992 Pasal 1 Asuransi (konvensional) adalah perjanjian antara dua pihak atau lebih, dengan mana seorang penanggung mengikatkan diri pada tertanggung dengan menerima premi asuransi, untuk memberi penggantian kepada tertanggung karena suatu kerugian, kerusakan atau kehilangan keuntungan yang diharapkan, yang mungkin akan diderita tertanggung yang timbul dari suatu peristiwa yang tidak pasti, atau untuk memberikan suatu pembayaran yang didasarkan atas meninggal atau hidupnya seseorang yang. Berdasarkan penjelasan tersebut, maka dalam asuransi terkandung empat unsur (Amrin, 2006: 7), yaitu :

1. Pihak tertanggung (insured)

2. Pihak penanggung (insurer)

3. Suatu peristiwa (accident)

4. Kepentingan (interest)

Selain itu di Indonesia juga dikenal adanya Asuransi dengan prinsip syariah. Menurut Fatwa DSN-MUI No. 21 Tahun 2001 tentang 
Astuti, et al/Jurnal Ekonomi Syariah Teori dan Terapan Vol. 4 No. 8 Agustus 2017: 668-683; PERBEDAAN EFISIENSI PERUSAHAAN ASURANSI JIWA SYARIAH DAN KONVENSIONAL DI INDONESIA DENGAN METODE DATA ENVELOPMENT ANALYSIS (DEA)

Pedoman Umum Asuransi Syariah, Asuransi Syariah (Ta'min, Takaful atau Tadhamun) adalah usaha saling melindungi dan tolong-menolong di antara sejumlah orang/pihak melalui investasi dalam bentuk aset dan atau tabarru' yang memberikan pola pengembalian untuk menghadapi resiko tertentu melalui akad (perikatan) yang sesuai dengan syariah. Perbedaan antara Asuransi Syariah dan Konvensional selain akad juga terletak pada sisi kepemilikan dana, premi, risiko, investais, klaim dan profit.

\section{Konsep Efisiensi}

Menurut Mala (2015:17) efisiensi adalah perbandingan terbaik antara keluaran (output) dengan masukan (input). Efisiensi merupakan salah satu parameter kinerja yang secara teoritis mendasari seluruh kinerja sebuah organisasi. Menurut Rifki (2010:41) efisiensi adalah kemampuan untuk menyelesaikan suatu pekerjaan dengan benar atau dalam pandangan matematika didefinisikan sebagai perhitungan rasio output (keluaran) dan atau input (masuk) atau jumlah keluaran yang dihasilkan dari satu input yang digunakan. Suatu perusahaan dikatakan efisien apabila:

1. Menggunakan jumlah input yang lebih sedikit bila dibandingkan dengan jumlah unit input yang digunakan oleh perusahaan lain dengan menghasilkan output yang sama (orientasi input).

2. Menggunakan jumlah unit input yang sama dapat menghasilkan jumlah output yang lebih besar (orientasi utput).

Ada tiga bentuk dasar efisensi, yaitu :

1. Efisiensi Teknik yaitu memaksimalkan output yang mungkin dengan sejumlah input yang tersedia (Mala, 2015:17).

2. Efisiensi Alokasi yaitu menunjukkan kemampuan perusahaan dalam mengoptimalkan penggunaan inputnya, dengan struktur harga pasar dan anggaran produksi yang dimiliki (Moussawi dan Obeid, 2011: 12).

3. Efisiensi Biaya atau efisiensi ekonomi merupakan kombinasi antara technical efficiency dan allocative efficiency. (Mala, 2016).

\section{Efisiensi dalam Ekonomi Islam}

Konsep efisien seperti yang dicerminkan dalam surat Al-Israa' 26-27 :

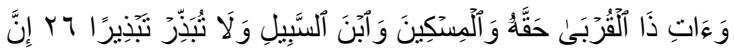

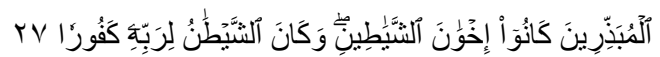

Wa,,āti-żalqurbā haqqahu walmiskina wabnassabili walā tubażir tabżìrā.,,innalmubażirīna-kā nū „ „ikhwānasysyayā țānu-lirabbihi kafūrā Artinya : "Dan berikanlah kepada keluarga-keluarga yang dekat akan haknya, kepada orang miskin dan orang yang dalam perjalanan dan janganlah kamu menghambur-hamburkan (hartamu) secara boros. Sesungguhnya pemboros-pemboros itu adalah saudarasaudara syaitan dan syaitan itu adalah sangat ingkar kepada Tuhannya" (QS AlIsraa' (17) 26-27).

Kata tabzir (pemborosan) dipahami oleh ulama dalam arti pengeluaran yang bukan haq. Jika seseorang menafkahkan semua hartanya dalam kebaikan dia bukanlah seorang 
Astuti, et al/Jurnal Ekonomi Syariah Teori dan Terapan Vol. 4 No. 8 Agustus 2017: 668-683; PERBEDAAN EFISIENSI PERUSAHAAN ASURANSI JIWA SYARIAH DAN KONVENSIONAL DI INDONESIA DENGAN METODE DATA ENVELOPMENT ANALYSIS (DEA)

pemboros. Sayyidina Abu Bakar ra menyerahkan semua hartanya kepada Nabi saw dalam rangka berjihad di jalan Allah sedangkan Sayyidina Utsman ra. membelanjakan separuh hartanya. Nafkah keduanya diterima Rasulullah saw dan beliau tidak menilai mereka sebagai pemboros. Sebaliknya jika membasuh wajah lebih dari tiga kali saat wudhu dinilai sebagai pemborosan, jika demikian pemborosan dinilai dari tempat dan kegunaan (Shihab, 2009:72).

Jika dikaitkan dengan kegiatan operasional asuransi, dibutuhkan ketelitian dan ketepatan dalam mengelola bebanbeban, baik itu beban operasional, beban administrasi, beban komisi, beban klaim yang didistribusikan kepada peseta yang mengalami musibah, dan lain sebagainya. Beban-beban tersebut harus dikelola secara efisien agar memberikan hasil yang maksimal pula bagi perusahaan.

\section{Efisiensi pada Asuransi Syariah dan Konvensional}

Menurut Berger dan Humphrey (1992) dalam Aksah (2013: 68-71) terdapat tiga pendekatan utama digunakan untuk mengukur output di sektor jasa keuangan yaitu pendekatan aset atau pendekatan intermediasi, pendekatan user-cost dan pendekatan nilai tambah. Pendekatan modifikasi nilai tambah dianggap yang paling sesuai untuk industri Asuransi. Pendekatan ini menggunakan komponen aset dan kewajiban perusahaan, yang meliputi kegiatan investasi, modal perusahaan dan beban-beban yang menjadi kewajiban perusahaan. Pendekatan nilai tambah ini juga pada akhirnya banyak dijadikan acuan oleh penelitian lainnya yang juga membahas mengenai efisiensi industry asuransi. Secara umum asuransi menyediakan tiga layanan:

1. Fungsi utama untuk mengelola resiko melalui program perlindungan yang tepat. Perusahaan asuransi jiwa umumnya menyediakan layanan asuransi kesehatan untuk karyawan dan termasuk layanan tambahan investasi berbentuk unit link.

2. Fungsi intermediasi, perusahaan asuransi mengumpulkan dana dari peserta dan menginvestasikan dana tersebut untuk menghasilkan pendapatan investasi yang nantinya akan berkontribusi terhadap pendapatan. Oleh karena itu, perusahaan asuransi juga memberikan fungsi nilai tambah melalui fungsi intermediasinya.

3. Melalui hasil investasi yang dilakukannya dengan dana pemegang polis, perusahaan asuransi meyalurkan kembali kepada pemegang polis yang mengalami kerugian.

Berdasarkan pendekatan nilai tambah yang dimodifikasi tersebut penelitian ini menggunakan pendekatan nilai tambah dengan variabel input meliputi total investasi, total modal, dan total beban sedangkan varibel output meliputi profit dan pendapatan investasi. Pendekatan nilai tambah dapat diartikan 
Astuti, et al/Jurnal Ekonomi Syariah Teori dan Terapan Vol. 4 No. 8 Agustus 2017: 668-683; PERBEDAAN EFISIENSI PERUSAHAAN ASURANSI JIWA SYARIAH DAN KONVENSIONAL DI INDONESIA DENGAN METODE DATA ENVELOPMENT ANALYSIS (DEA)

sebagai gabungan antara pendekatan produksi (operasional) dan pendekatan intermediasi/investasi. Hal tersebut berkaitan dengan kegiatan operasional perusahaan Asuransi Jiwa dalam mengelola seluruh beban dan modal dalam menghasilkan laba bagi perusahaan sedangkan pendekatan investasi berkaitan dengan fungsi perusahaan sebagai wakil dari peserta dalam melakukan kegiatan investasi sehingga menghasilkan pendapatan yang nantinya akan dibagi kepada peserta.

\section{Data Envelopment Analysisi (DEA)}

Model statistik non parametrik Data Envelopment Analysis (DEA).adalah tes yang modelnya tidak menetapkan syarat-syarat mengenai parameter populasi yang merupakan induk sampel penelitiannya (Nur Sabrina, 2013:48). DEA adalah suatu pendekatan non parametrik yang merupakan teknik berbasis linier programming menggunakan multiple input untuk menghasilkan multiple output (Begum, 2013:49-50).

Suatu DMU dikatakan efisien secara relatif apabila nilai dualnya sama dengan 1 (nilai efisiensi 100 persen) namun sebaliknya apabila nilai dualnya kurang dari 1 maka DMU bersangkutan dianggap tidak efisien secara relatif (Nugroho, 1995 dalam Huri dan Susilowati, 2004).

Terdapat dua model pendekatan DEA, di antaranya:

1. Constant Return to Scale (CRS) Model Constant Return to Scale dikembangkan oleh Charnes,
Cooper dan Rhodes (model CRS dapat disebut juga sebagai model CCR) pada tahun 1978. Model ini mengasumsikan bahwa rasio antara penambahan input dan output adalah sama (constant return to scale). Jika terdapat tambahan input 1\%, maka output juga akan meningkat sebesar $1 \%$ (Sari, 2015:40). Asumsi lain yang digunakan dalam model ini adalah setiap perusahaan atau Decision Making Units (DMU) beroperasi pada skala optimal. Pengukuran efisiensi dengan model CCR merupakan pengukuran overall technical efficiency (OTE) yang merupakan hasil pengalian antara efisiensi teknis dan efisiensi skala (TE $x$ SE). Program liner konsep efisiensi dengan model CCR dapat dirumuskan sebagai berikut (Moussawi dan Obeid, 2011: 13) :

$\operatorname{Max} h_{k}=\frac{\sum_{r=1}^{s} u_{r} y_{r j}}{\sum_{i=1}^{m} u_{i} x_{i j}}$

Dimana:

$h_{k}=$ Nilai efisiensi operasional

$\sum_{r=1}^{s} u_{r} y_{r j}=$ Output terbobot

$\sum_{i=1}^{m} u_{i} x_{i j}=$ Input terbobot

Dengan fungsi kendala:

$\frac{\sum_{r=1}^{s} u_{r} y_{r j}}{\sum_{i=1}^{m} u_{i} x_{i j}} \leq 1$

$U_{i} \geq 0, y_{i} \geq 0$

2. Variable Return to Scale (VRS)

Model ini dikembangkan oleh Banker, Charnes dan Rhodes (dapat juga disebut dengan model BCC) pada tahun 1984 dan 
Astuti, et al/Jurnal Ekonomi Syariah Teori dan Terapan Vol. 4 No. 8 Agustus 2017: 668-683; PERBEDAAN EFISIENSI PERUSAHAAN ASURANSI JIWA SYARIAH DAN KONVENSIONAL DI INDONESIA DENGAN METODE DATA ENVELOPMENT ANALYSIS (DEA)

merupakan pengembangan dari model CRS. Model ini berasumsi bahwa rasio antara penambahan input dan output tidak sama (variable return to scale), artinya penambahan input sebesar $1 \%$ tidak akan menyebabkan output meningkat sebesar 1\%, bisa lebih kecil (decreasing return to scale) atau lebih besar dari $1 \%$ (increasing return to scale).

Rumus Variable Return to scale (VRS) dapat dituliskan dengan program linier sebagai berikut :

$\min h_{k}$

$\sum_{j=1}^{n} u_{j} y_{r j} \geq$

$y_{r k}$

$\sum_{j=1}^{n} u_{j} x_{i j} \leq$

$h_{k} x_{i k}$

)

$u_{j} \geq 0$

Berbeda dengan CCR model yang mengukur efisiensi teknis dan efisiensi skala dari suatu DMU, pada BCC model hanya mengukur efisieni teknis dari suatu DMU (pure technical efficiency).

\section{HIPOTESIS PENELITIAN}

Berdasarkan latar belakang, rumusan masalah, tujuan penelitian, landasan teori yang telah dikemukakan maka hipotesis dalam penelitian ini adalah :

H1: Terdapat perbedaan efisiensi operasional yang signifikan dengan asumsi CRS pada Asuransi Jiwa Syariah dan Asuransi Jiwa Konvensional di Indonesia .
H2: Terdapat perbedaan efisiensi operasional yang signifikan dengan asumsi VRS pada Asuransi Jiwa Syariah dan Asuransi Jiwa Konvensional di Indonesia .

\section{METODE PENELITIAN}

\section{Pendekatan Penelitian}

Pendekatan yang digunakan dalam penelitian ini adalah penelitian kuantitatif dengan alat analisis kuantitatif Data Envelopment Analysis (DEA)

\section{Variabel Input}

\section{Total Modal}

Jumlah modal pada perusahaan asuransi jiwa merupakan total dari ekuitas disajikan sesuai dengan prinsip akuntansi yang berlaku umum (PSAK No. 36 Akuntansi Asuransi Jiwa). Ekuitas terdiri atas setoran pemilik yang seringkali disebut modal atau simpanan pokok anggota untuk badan hukum koperasi, saldo laba, dan unsur lain (PSAK No. 21 Akuntansi Ekuitas).

\section{Total Investasi}

Total investasi terdiri dari total investasi yang dilakukan perusahaan atas pendapatan premi/ kontribusi yang diterima.

\section{Total Beban}

Berdasarkan laporan keuangan perusahaan maka indikator total beban perusahaan Asuransi Syariah adalah seluruh total beban yang meliputi beban klaim, beban pengelolaan investasi (pada laporan laba/rugi dana Tabarru'), dan total beban operasional (pada laba/rugi dana perusahaan). Total beban Asuransi Jiwa Konvensional adalah total seluruh beban yang dimiliki perusahaan. 
Astuti, et al/Jurnal Ekonomi Syariah Teori dan Terapan Vol. 4 No. 8 Agustus 2017: 668-683; PERBEDAAN EFISIENSI PERUSAHAAN ASURANSI JIWA SYARIAH DAN KONVENSIONAL DI INDONESIA DENGAN METODE DATA ENVELOPMENT ANALYSIS (DEA)

\section{Variabel Output}

\section{Pendapatan Investasi}

Pendapatan hasil dari investasi yang dilakukan perusahaan, investasi dapat berupa deposito berjangka, obligasi, sukuk, saham, saham syariah, reksadana, dan lain sebagainya.

\section{Profit}

Pada pengukuran efisiensi menggunakan model DEA, penentuan variabel output harus berdasarkan variabel dengan nilai positif, sehingga unsur loss atau kerugian dari perusahaan tidak dapat diukur dan dianalisis lebih lanjut.

\section{Populasi dan Sampel}

Populasi dalam penelitian ini adalah seluruh Asuransi Jiwa Syariah dan Konvensioal yang ada di Indonesia. Pengambilan sampel dalam penelitian ini dilakukan dengan purposive sampling.

\section{Jenis dan Sumber Data}

Data yang digunakan dalam penelitian ini adalah data sekunder berupa laporan keuangan tahunan perusahaan asuransi tahun 2012 sampai 2015.

\section{Teknik Analisis Data}

\section{Data Envelopment Analysis}

Variabel input dan output yang telah ditentukan sebelumnya akan dianalisis menggunakan model Constan Return to Scale (CRS) dan model Variable Return to Scale (VRS) untuk mengetahui nilai efisiensi ekonomi dan efisiensi teknis. Efisiensi dengan metode DEA pada penelitian ini menggunakan orientasi input.

\section{Uji Hipotesis}

Setalah dilakukan perhitungan efisieni untuk masing-masing Asuransi Jiwa Syariah dan Asuransi Jiwa Konvensional, maka analisis data selanjutnya adalah pengujian hipotesis terhadap keduanya. Model yang digunakan untuk menguji hipotesis tersebut adalah uji beda Mann-Whitney U-Test dengan SPSS 20. Model perhitungan nilai uji statistik MannWhitney U-Test adalah :

$$
U_{1 \text { hitung }}=n_{1} n_{2} \frac{n_{1}\left(n_{1}+1\right)}{2}-\sum R_{2}
$$

Atau

$$
U_{2 \text { hitung }}=n_{1} n_{2} \frac{n_{2}\left(n_{2}+1\right)}{2}-\Sigma R_{2}
$$

Dimana: $U_{1}$ : Statistik uji $U_{1}$

$U_{2}$ : Statistik uji $U_{2}$

$n_{1}$ : jumlah sampel grup sampel lebihbesar $n_{2}$ : jumlah sampel grup sampel lebih kecil $R_{1}$ : Jumlah rank sampel grup sampel yang lebih besar

$R_{2}$ : Jumlah rank sampel grup sampel yang lebih kecil

\section{HASIL DAN PEMBAHASAN}

\section{Analisis Komparasi Nilai Efisiensi Model} CRS dan VRS

Berdasarkan hasil komparasi terdapat dua jenis perbandingan yaitu perbandingan komposisi nilai efisiensi dan nilai rata-rata efisiensi. Pertama perbandingan komposisi nilai efisiensi meliputi komposisi relatif efisien dan komposisi nilai efisiensi tiap tahun. Komposisi relatif efisien merupakan komposisi perusahaan yang setidaknya 
Astuti, et al/Jurnal Ekonomi Syariah Teori dan Terapan Vol. 4 No. 8 Agustus 2017: 668-683; PERBEDAAN EFISIENSI PERUSAHAAN ASURANSI JIWA SYARIAH DAN KONVENSIONAL DI INDONESIA DENGAN METODE DATA ENVELOPMENT ANALYSIS (DEA)

pernah sekali mencapai efisiensi pada rentang tahun 2012-2015. Komposisi tiap tahun merupakan besarnya presentase perusahaan yang efisien pada tahun tersebut. Kedua jenis komposisi dengan asumsi CRS dan VRS menunjukkan presentase Asuransi Jiwa Konvensional lebih besar.

Tabel 4.1

Perbandingan Nilai Overall Tecnical Efficiency atau CRS Pada Asuransi Jiwa Syariah dan Konvensional 2012-2015

\begin{tabular}{|c|l|c|}
\hline Kelompok Asuransi & \multicolumn{2}{|c|}{ CRS } \\
\hline \multirow{4}{*}{ Asuransi Jiwa Syariah } & Mean & 0,845 \\
\cline { 2 - 3 } & Min & 0,369 \\
\cline { 2 - 3 } & Max & 1 \\
\cline { 2 - 3 } & SD & 0,184 \\
\hline \multirow{3}{*}{$\begin{array}{c}\text { Asuransi Jiwa } \\
\text { Konvensional }\end{array}$} & Mean & 0,884 \\
\cline { 2 - 3 } & Min & 0,27 \\
\cline { 2 - 3 } & Max & 1 \\
\cline { 2 - 3 } & SD & 0,199 \\
\hline
\end{tabular}

Kedua merupakan perbandingan nilai rata-rata efisiensi dalam rentang tahun 2012-2015 dan perbandingan nilai rata-rata efisiensi setiap tahun. Hasil perbandingan tersebut menunjukkan bahwa nilai rata-rata efisiensi setiap tahun maupun keseluruhan menghasilkan nilai yang relatif sama antara perusahaan Asuransi Jiwa Syariah dan Konvensional dengan asumsi CRS dan VRS. Berdasarkan hasil tersebut dapat disimpulkan bahwa meskipun secara komposisi Asuransi Jiwa Konvensional memiliki nilai yang lebih besar namun pada perbandingan ratarata keduanya tetap memiliki nilai efisiensi yang relatif sama.
Tabel 4.2

Perbandingan Nilai Pure Tecnical Efficiency Pada Asuransi Jiwa Syariah dan Konvensional 2012-2015

\begin{tabular}{|c|l|c|}
\hline Kelompok Asuransi & \multicolumn{2}{|c|}{ VRS } \\
\hline \multirow{4}{*}{ Asuransi Jiwa Syariah } & Mean & 0,923 \\
\cline { 2 - 3 } & Min & 0,445 \\
\cline { 2 - 3 } & Max & 1 \\
\cline { 2 - 3 } & SD & 0,131 \\
\hline \multirow{4}{*}{$\begin{array}{c}\text { Asuransi Jiwa } \\
\text { Konvensional }\end{array}$} & Mean & 0,927 \\
\cline { 2 - 3 } & Min & 0,29 \\
\cline { 2 - 3 } & Max & 1 \\
\cline { 2 - 3 } & $S D$ & 0,191 \\
\hline
\end{tabular}

\section{Uji Normalitas}

\section{Hasil Uji Normalitas}

Hasil uji normalitas pada Tabel 4.16 menunjukkan bahwa dari kedua kelompok data (CRS dan VRS) dan kedua kelompok sampel (Asuransi Jiwa Syariah dan Konvensional), keduanya memiliki nilai signifikansi lebih kecil dari nilai $a=0,05$ sehingga dari kedua kelompok data memang benar-benar menunjukkan kelompok yang tidak terdistribusi secara normal. Oleh sebab itu karena kelompok data tidak terdistribusi secara normal dan jenis data yang merupakan data interval dengan besar sampel yang tidak sama antara kedua kelompok sampel, maka model analisis yang dapat digunakan adalah model non-parametrik independent sample Mann-Whitney U-Test apabila pada uji homogenitas menunjukkan data bersifat homogen. 
Astuti, et al/Jurnal Ekonomi Syariah Teori dan Terapan Vol. 4 No. 8 Agustus 2017: 668-683; PERBEDAAN EFISIENSI PERUSAHAAN ASURANSI JIWA SYARIAH DAN KONVENSIONAL DI INDONESIA DENGAN METODE DATA ENVELOPMENT ANALYSIS (DEA)

Tabel 4.3

Tests of Normality

\begin{tabular}{|c|l|r|r|r|r|r|r|}
\hline \multicolumn{2}{|c|}{} & \multicolumn{3}{|c|}{$\begin{array}{c}\text { Kolmogorov- } \\
\text { Smirnova }\end{array}$} & \multicolumn{3}{c|}{ Shapiro-Wilk } \\
\cline { 2 - 8 } \multicolumn{2}{|c|}{} & Statistic & \multicolumn{1}{|c|}{ Df } & Sig. & Statistic & Df & Sig. \\
\hline \multirow{2}{*}{ CRS } & SYARIAH & .224 & 52 & .000 & .819 & 52 & .000 \\
\cline { 2 - 8 } & KONVEN & .305 & 20 & .000 & .642 & 20 & .000 \\
\hline \multirow{2}{*}{ VRS } & SYARIAH & .345 & 52 & .000 & .659 & 52 & .000 \\
\cline { 2 - 8 } & KONVEN & .429 & 20 & .000 & .443 & 20 & .000 \\
\hline
\end{tabular}

a. Lilliefors Significance

Correction

\section{Hasil Uji Homogenitas}

Pada Tabel 4.17 dapat dilihat bahwa untuk kedua kelompok data nilai efisiensi model CRS dan VRS memiliki signifikansi lebih dari $a=0,05$ sehingga dapat dikatakan data bersifat homogen yang artinya memiliki varians yang sama. Asumsi homogenitas pada kelompok data ini terpenuhi sehingga uji hipotesis dengan model statistik Mann-Whitney U-test dapat dilanjutkan.

Tabel 4.4

\section{Hasil Uji Homogenitas}

Test of Homogeneity of Variance

\begin{tabular}{|l|r|r|r|r|}
\hline & $\begin{array}{r}\text { Levene } \\
\text { Statistic }\end{array}$ & df1 & df2 & Sig. \\
\hline CRS $\begin{array}{l}\text { Based on Mean } \\
\text { Based on }\end{array}$ & .317 & 1 & 70 & .575 \\
$\begin{array}{l}\text { Median } \\
\text { Based on } \\
\text { Median and with } \\
\text { adjusted df }\end{array}$ & .661 & 1 & 70 & .419 \\
$\begin{array}{l}\text { Based on } \\
\text { trimmed mean }\end{array}$ & .661 & 1 & 60.669 & .420 \\
VRS $\begin{array}{l}\text { Based on Mean } \\
\text { Based on } \\
\text { Median }\end{array}$ & .334 & 1 & 70 & .565 \\
$\begin{array}{l}\text { Based on } \\
\text { Median and with } \\
\text { adjusted df } \\
\text { Based on } \\
\text { trimmed mean }\end{array}$ & .014 & 1 & 70 & .907 \\
\hline
\end{tabular}

Uji Beda Independent Sample MannWhitney U-Test

Tabel 4.5

Hasil Mann-Whitney U-Test

Test Statistics ${ }^{a}$

\begin{tabular}{|c|c|c|}
\hline & CRS & VRS \\
\hline Mann-Whitney U & 415.000 & 452.000 \\
Wilcoxon W & 1793.000 & 1830.000 \\
Z & -1.371 & -1.006 \\
Asymp. Sig. (2-tailed) & .171 & .314 \\
\hline
\end{tabular}

a. Grouping Variable: Kode

Tabel 4.18 menunjukkan bahwa untuk nilai efisiensi asumsi CRS memiliki nilai U sebesar 415 dengan nilai signifikansi sebesar 0,171 atau lebih dari nilai a=0,05. Hal tersebut berarti $\mathrm{HO}$ diterima dan $\mathrm{HI}$ ditolak. Nilai efisiensi asumsi memiliki nilai $U$ sebesar 452 dengan nilai signifikansi sebesar 0,314 atau lebih dari nilai a=0,05. $\mathrm{Hal}$ tersebut berarti $\mathrm{HI}$ ditolak sehingga dapat disimpulkan bahwa tidak terdapat perbedaan yang signifikan nilai efisiensi operasional dengan asumsi VRS dan CRS pada Asuransi Jiwa Syariah dan Konvensional di Indonesia.

\section{Pembahasan Hipotesis}

Hasil penilaian DEA ini menunjukkan bahwa nilai rata-rata relatif perusahaan Asuransi Jiwa Syariah dan Konvensional lebih efisien dengan asumsi VRS dibandingkan asumsi CRS. Hal ini mengindikasikan bahwa secara relatif, sumber inefisiensi operasional adalah ketidakoptimalan pada nilai efisiensi skala.

Hasil pengolahan DEA dengan asumsi CRS maupun VRS menunjukkan 
Astuti, et al/Jurnal Ekonomi Syariah Teori dan Terapan Vol. 4 No. 8 Agustus 2017: 668-683; PERBEDAAN EFISIENSI PERUSAHAAN ASURANSI JIWA SYARIAH DAN KONVENSIONAL DI INDONESIA DENGAN METODE DATA ENVELOPMENT ANALYSIS (DEA)

bahwa terdapat perusahaan yang relatif stabil mengalami efisiensi dari tahun 20122015 meliputi Asuransi Jiwa Unit Syariah Prudential dan Asuransi Jiwa Konvensional Equity Life. Kedua perusahaan tersebut dapat dijadikan acuan bagi perusahaan asuransi pada industri masing-masing dalam menentukan target penetapan input dan output. Hasil penetapan target tahun 2015 dengan asumsi VRS hampir semua perusahaan yang belum mencapai efisiensi menggunakan kedua asuransi tersebut dalam menentukan target.

Hasil pengujian hipotesis dengan model Mann-Whitney U-Test menunjukkan bahwa untuk nilai efisiensi perusahaan Asuransi Jiwa Syariah dan Konvensional dengan asumsi CRS tidak terdapat perbedaan yang signifikan. Nilai median kedua kelompok menujukkan hasil yang berbeda namun nilai rata-rata keduanya relatif sama. Adanya HI yang ditolak pada asumsi CRS menunjukkan bahwa antara perusahaan Asuransi Jiwa Syariah dan Konvensional pada ukuran (size) yang setara secara umum tidak memiliki perbedaan efisiensi dalam mengelola faktor-faktor input untuk menghasilkan output yang optimal (Sari, 2015: 103).

$$
\text { Hasil uji Mann-Whitney U-Test }
$$
dengan asumsi VRS juga menunjukkan bahwa tidak terdapat perbedaan yang signifikan nilai efisiensi dengan asumsi VRS pada perusahaan Asuransi Jiwa Syariah dan Konvensional di Indonesia. Adanya $\mathrm{H} 2$ yang ditolak menunjukkan bahwa secara murni atau secara teknik kedua sampel pada Ukuran perusahaan yang setara tidak memiliki perbedaan dalam kemampuan managerial pengelolaan faktor input menjadi output. Median dan mean dari kedua kelompok juga menunjukkan nilai yang relatif sama. Berdasarkan hasil pengolahan dan interpretasi data menunjukkan bahwa meskipun dengan market share yang sangat sedikit Asuransi Jiwa Syariah mampu mencapai efisiensi yang setara dengan Asuransi Jiwa Konvensional. Asuransi Jiwa Syariah memiliki potensi untuk meningkatkan rata-rata efisiensi melebihi Asuransi Jiwa Konvensional dengan kekuatan pasar yang lebih besar. Upaya untuk memunculkan perbedaan diantara keduanya dapat ditempuh dengan meningkatkan nilai efisiensi tiap perusahaan sehingga dapat meningkatkan pula rata-rata efisiensi tiap kelompok agar berbeda dengan kelompok sampel lain. Hal tersebut dikarenakan besarnya nilai rata-rata merupakan penyebab dari nilai $P$ Value yang besar sehingga tidak ada perbedaan.

\section{SIMPULAN}

Berdasarkan hasil analisis dan interpretasi data yang dilakukan maka dapat diambil kesimpulan sebagai berikut:

1. Tidak terdapat perbedaan efisiensi operasional dengan asumsi CRS dan VRS pada Asuransi Jiwa Syariah dan Konvensional yang ditunjukkan dengan nilai signifikansi uji beda Mann-Whitney U-Test lebih dari nilai $\mathrm{a}=0,05$ ( $\mathrm{H} 1$ ditolak). 
Astuti, et al/Jurnal Ekonomi Syariah Teori dan Terapan Vol. 4 No. 8 Agustus 2017: 668-683; PERBEDAAN EFISIENSI PERUSAHAAN ASURANSI JIWA SYARIAH DAN KONVENSIONAL DI INDONESIA DENGAN METODE DATA ENVELOPMENT ANALYSIS (DEA)

2. Hasil dari uji non-parametrik MannWhitney U-Test menolak hipotesis yang pertama dengan asumsi CRS karena meskipun memiliki median yang berbeda namun nilai rata-rata relatif sama. Median dari Asuransi Jiwa Syariah sebesar 0,93 sedangkan Asuransi Jiwa Konvensional sebesar satu.

3. Uji Mann-Whitney U-Test dengan asumsi VRS juga menolak hipotesis kedua karena kedua sampel bahkan memiliki median dan mean yang relatif sama.

4. Hasil pengolahan data menunjukkan bahwa dengan market share yang jauh lebih kecil, Asuransi Jiwa Syariah mampu mencapai nilai rata-rata efisiensi yang relatif sama dengan Asuransi Jiwa Konvensional. Apabila Asuransi Jiwa Syariah meningkatkan market share maka tidak menutup kemungkinan jika nilai efisiensi yang dapat dicapai akan melebihi nilai efisiensi Asuransi Jiwa Konvensional.

5. Berdasarkan hasil pengolahan DEA menunjukkan bahwa terdapat perusahaan yang relatif stabil mengalami efisiensi dari tahun 20122015 meliputi Asuransi Jiwa Unit Syariah Prudential dan Asuransi Jiwa Konvensional Equity Life. Kedua perusahaan tersebut dapat dijadikan acuan bagi perusahaan asuransi pada industri masing-masing dalam menentukan target penetapan input dan output.
6. Perusahaan Asuransi Unit Syariah AIA Financial, Asuransi Unit Syariah Sinar Mas, dan Asuransi Full Syariah Takaful Life tidak dapat dijadikan benchmark bagi perusahaan lain karena tidak pernah mencapai efisiensi CRS maupun VRS tahun 2012-2015.

\section{DAFTAR PUSTAKA}

Adu, Kwadjo Ansah, et al. 2012. Evaluating The Cost Efficiency of Insurance Companies in Ghana. Journal of Risk Finance, 13 (1): 61-76.

Akbar, Rifki Ali. 2010. Analisis Efisiensi Baitul Mal Wa Tamwil Dengan Menggunakan Data Envelopment Analysis (DEA). Skripsi tidak diterbitkan. Universitas Diponegoro.

Aksah, Diana Yoseva. 2013. Analisis Efisiensi Industri Asuransi di Indonesia. Tesis tidak diterbitkan. Universitas Indonesia.

Ali, Zainuddin. 2008. Hukum Asuransi Syariah. Jakarta: Sinar Grafika.

Amrin, Abdullah. 2006. Asuransi Syariah. Jakarta: PT Elex Media Komputindo.

Anshori, Muslich dan Sri Iswati. 2009. Metode Penelitian Kuantitatif. Surabaya: Pusat Penerbitan dan Percetakan UNAIR.

Ascarya dan Yumanita. 2008. Comparing the Efficiency of Islamic Banks in Malaysia and Indonesia. Buletin Ekonomi Moneter dan Perbankan, Vol.11 (2): 95-119

Asosiasi Asuransi Syariah Indonesia. 2014. Data Bisnis $2014 . \quad$ (Sumber: http://www.aasi.or.id/ main/data-bisnis2014, diakses pada tanggal 30 Agustus 2016). 
Astuti, et al/Jurnal Ekonomi Syariah Teori dan Terapan Vol. 4 No. 8 Agustus 2017: 668-683; PERBEDAAN EFISIENSI PERUSAHAAN ASURANSI JIWA SYARIAH DAN KONVENSIONAL DI INDONESIA DENGAN METODE DATA ENVELOPMENT ANALYSIS (DEA)

Asosiasi Asuransi Syariah Indonesia. 2015.

Data Bisnis 2015. (Sumber:

http://www.aasi.or.id/main/ data-bisnis-

2015, diakses pada tanggal 30 Agustus 2016).

Asura. Tanpa Tahun. Sejarah dan Perkembangan Asuransi di Indonesia. (Sumber: https://www. asura.co.id/blog/sejarah-dan-

perkembang an-asuransi-di-indonesia, diakses pada tanggal 11 September 2016).

Begum, Nur Sabrina. 2015. Analisis Tingkat Efisiensi Perbankan Syariah Di Indonesia Tahun 2010 - 2014 Dengan Menggunakan Metode Data Envelopment Analysis. Skripsi tidak diterbitkan. Universitas Airlangga.

Eling, Martin dan Michael Luhnen. 2009.

The Performance of Microinsurance Programs: A Frontier Efficiency Analysis (Online). (http;//actuaria.org, diakses 1 Oktober 2016).

--------. 2010. Efficiency in The International Insurance Industry: A Cross-Country Comparison. Journal of Banking and Finance, 34: 1497-1509.

Fatwa Dewan Syari'ah Nasional No: 21/DSN-MUI/X/2001 Tentang Pedoman Umum Asuransi Syari' ah.

Fatwa Dewan Syari'ah Nasional No: 53/DSN-MUI/III/2006 Tentang Akad Tabarru' Pada Asuransi Syari'ah.

Hasibuan, Putra Halomoan. 2016. Analisis Hukum Asuransi Syariah Dengan Hukum Asuransi Konvensional. Jurnal Hukum Ekonomi, Vol 2(1): 58.
Huri, Mumu Daman And Susilowati, Indah. 2004. Pengukuran Efisiensi Relatif Emiten Perbankan Dengan Metode Data Envelopment Analysis (Studi Kasus: Bank-Bank Yang Terdaftar Di Bursa Efek Jakarta Tahun 2002). Jurnal Dinamika Pembangunan (Jdp), Volume 1 (Nomor 2). Pp. 95-110.

Ikatan Akuntan Indonesia. 1996.

Pernyataan Standar Akuntansi

Kevangan No. 36 Tentang Akuntansi Asuransi Jiwa. Komite Standar Akuntansi Keuangan. Jakarta.

Ikatan Akuntan Indonesia. 1994.

Pernyataan Standar Akuntansi Keuangan (PSAK) No. 21 tentang Akuntansi Ekuitas. Komite Standar Akuntansi Keuangan. Jakarta.

Ikatan Akuntan Indonesia. 2010. Pernyataan Standar Akuntansi Keuangan No. 108 Tentang Akuntansi Transaksi Asuransi Syariah. Komite Standar Akuntansi Keuangan. Jakarta. Kitab Undang Undang Hukum Dagang Pasal 246 Tentang Pengertian Asuransi. Mala, Ainul. 2015. Evaluasi Efisiensi Dan Faktor-Faktor Yang Mempengaruhi Efisiensi Perusahaan Asuransi Di Indonesia Periode 2008-2010. Skripsi tidak diterbitkan. Universitas Airlangga. Mawaddah, Imaroh. 2013. Efficiency Performance Analysis of Indonesia General Insurance Companies (20082012). Skripsi tidak diterbitkan. Universitas Airlangga.

Moussawi, Chawki EL dan Hassan Obeid. 2011. Evaluating the Productive Efficiency of Islamic 
Astuti, et al/Jurnal Ekonomi Syariah Teori dan Terapan Vol. 4 No. 8 Agustus 2017: 668-683; PERBEDAAN EFISIENSI PERUSAHAAN ASURANSI JIWA SYARIAH DAN KONVENSIONAL DI INDONESIA DENGAN METODE DATA ENVELOPMENT ANALYSIS (DEA)

Banking in GCC: A Non-Parametric Approach. International Management Review, Vol 7(1) pp.10-21

Muhammad. 2007. Lembaga Ekonomi Syariah. Yogyakarta: Graha IImu.

Muharam, H dan Pusvitasari. 2007. Analisis Perbandingan Efisiensi Bank Syariah dengan Metode Data

Envelopment Analysis (periode tahun 2005). Jurnal Ekonomi dan Bisnis Islam, Vol.2 No.3.

Otoritas Jasa Keuangan (OJK). 2016. Statistik Perbankan Syariah Juni 2016.(Sumber: http://www.ojk.go.id /statistik-perbankan-Syariah-januari 2015, diakses pada tanggal 22 Januari 2015)

Otoritas Jasa Kevangan (OJK). 2016. Daftar Perusahaan Asuransi Umum, Jiwa dan Reasuransi dengan Prinsip Syariah 2016.2 (Sumber: http://www.ojk.go.id/id/Daftar-

Perusahaan-Asuransi-Umum,-Jiwa-dan Reasuransi-dengan-Prinsip-Syariah, diakses pada tanggal 9 Oktober 2016).

Patriana, Ela. 2014. Model Penghitungan Tarif Premi Asuransi Syariah Dalam Hubungannya Dengan Segmentasi Pasar Dan Laba Perusahaan. Jurnal Etikonomi. 13(2): 187

Prihantoro, dkk. 2013. Analisis Faktor-Faktor Makro Ekonomi dan Demografi Terhadap Fungsi Permintaan Asuransi Jiwa di Indonesia. Jurnal Asuransi dan Manajemen Risiko, 1 (1): 33.

Puspitasari, Novi. 2011. Sejarah dan Perkembangan Asuransi Islam serta Perbedaannya dengan Asuransi
Konvensional. Jurnal Ekonomi Akuntansi dan Manajemen, 10(1): 38.

Rahim, Hendrisman. 2013. Optimisme Pertumbuhan Asuransi Indonesia: Proyeksi Perkembangan Lima Tahun (2014-2018). Jurnal Asuransi dan Manajemen Risiko, Vol 1 (2): 5-6.

Republik Indonesia. 2011. Peraturan Menteri Kevangan Nomor 11/Pmk.010/2011 Tentang Kesehatan Keuangan Usaha Asuransi Dan Usaha Reasuransi Dengan Prinsip Syariah. Kementrian Kevangan. Jakarta.

Republik Indonesia. 1992. Peraturan Pemerintah Republik Indonesia Nomor 73 Tahun 1992 Tentang Penyelenggaraan Usaha Perasuransian. Sekretariat Negara. Jakarta.

Republik Indonesia. 2008. Peraturan Pemerintah Republik Indonesia Nomor 81 Tahun 2008 Tentang Perubahan Ketiga Atas Peraturan Pemerintah Nomor 73 Tahun 1992 Tentang Penyelenggaraan Usaha Perasuransian. Sekretariat Negara. Jakarta.

Republik Indonesia. 2010. Undang-Undang Republik Indonesia Nomor 40 Tahun 2014 Tentang Perasuransian. Sekretariat Negara. Jakarta.

Rochma, Malia. 2007. Prospek Industri Asuransi Jiwa Di Indonesia. Economic Review, (210): 4.

Sari, Ditta Feicyllia. 2015. Analisis Efisiensi Pembiayaan Bank Umum Syariah Dan Bank Umum Konvensional Di Indonesia Dengan Metode Data Envelopment Analysis (DEA). Skripsi tidak diterbitkan. Universitas Airlangga. 
Astuti, et al/Jurnal Ekonomi Syariah Teori dan Terapan Vol. 4 No. 8 Agustus 2017: 668-683; PERBEDAAN EFISIENSI PERUSAHAAN ASURANSI JIWA SYARIAH DAN KONVENSIONAL DI INDONESIA DENGAN METODE DATA ENVELOPMENT ANALYSIS (DEA)

2015. Membandingkan Efisiensi

Pembiayaan Bank Umum Syariah Dan

Bank Umum Konvensional Di Indonesia Dengan Metode Data Envelopment Analysis (Dea). JEST, Vol 2(8): 678-679.

Shihab, M Quraish. 2009. Tafsir Al-Mishbah. Jakarta: Lentera Hati.

Soepeno, Bambang. 2002. Statistik Terapan: Dalam Penelitian Ilmu-ilmu Sosial dan Pendidikan. Jakarta: Rineka Cipta.

Sula, Muhammad Syakir. 2004. Asuransi Syariah: Life And General : Konsep Dan Sistem Operasional. Jakarta: Gema Insani Press. 